\title{
SPRING BIRD PHENOLOGY ON ST. LAWRENCE ISLAND, ALASKA
}

by Spencer G. Sealy, Dept. of Zoology, U.B.C., Vancouver, B.C.

During the summer of 1966, the writer was able to record the first arrival of a number of species of Alaska birds when he was stationed near Gambell (63' 51" N, 171'36" W) on St. Lawrence Island, studying the breeding biology of two species of plankton-feeding alcids. Field work

\section{TABLE 1 - BIRD PHENOLOGY CHART}

Gambell, St. Lawrence Island, Alaska

Arrival Date, 1966

Species

Arrival Date, Fay and Cade, (1959)

Pelagic Cormorant (Phalacrocorax pelagicus)....

* Emperor Goose (Philacte canagica)

* Oldsquaw (Clangula hyemalis)

* Common Eider (Somateria mollissima).

King Eider (Somateria spectabilis)

* Glaucous Gull (Larus hyperboreus)

* Herring Gull (Larus argentatus)...

* Ivory Gull (Pagophila eburnea)

- Black-legged Kittiwake (Rissa tridactyla.).

Common Murre (Uria aalge).

* Thick-billed Murre (Uria lomvia)

- Snow Bunting (Plectrophenax nivalis)

Sandhill Crane (Grus canadensis)

May 15

May 17

May 19

May 20

May 21

May 21

May 23

May 23

May 23

May 24

Wheatear (Oenanthe oenanthe)

Parasitic Jaeger (Stercorarius parasiticus)

Lapland Longspur (Calcarius lapponicus)

Steller's Eider (Polysticta stelleri)

Red Phalarope (Phalaropus fulicarius)

Long-tailed Jaeger (Stercorarius longicaudus)....

Pintail (Anas acuta).

American Golden Plover (Pluvialis dominica)....

Ruddy Turnstone (Arenaria interpres)

Rock Sandpiper (Erolia ptilocnemis).

Dunlin (Erolia alpina)

Semipalmated Plover (Charadrius semipalmatus)

Gyrfalcon (Falco rusticolus)

Horned Puffin (Fratercula corniculata)

Western Sandpiper (Ereunetes mauri).

May 25

May 26

May 28

May 28

May 29

May 29

May 30

May 30

May 30

May 30

May 30

May 31

June 1

June 1

June 6 late April

May 10

resident

early May

April

April

"early spring"

May 10

late April

May 19

May 1

middle May

middle May

middle May

May 20

early June

May 16

April

May 24, 1956, 23 miles south

Gambell

May 20

late May

May 20-30

late May

May

May 19

May 28

May 21

May 15-20

Species present at the time of my arrival in Gambell on May 13, 1966

March, 1967 
began on May 13 and continued till September 14. Observations presented here were made on land within a three-mile northeast-to-south radius of Gambell on the northwest cape of the island and offshore on the Bering Sea. Typical winter conditions prevailed until about the end of the first week of June with temperatures ranging between $28^{\circ} \mathrm{F}$. and $40^{\circ} \mathrm{F}$. By June 3 snow melt had begun on Sevuokuk Mountain, about two miles east of Gambell, and on portions of the tundra. The Bering Sea ice had broken into floe ice about the middle of April providing leads and open water where seabirds abounded.

Phenology concerns itself with a study of the phenomena of plant and animal life in relation to seasonal changes. The scientific value of phenological data has been aptly discussed and defended by Glendenning (1943) and Leopold and Jones (1947). The former author states that phenological data may be of no scientific value if nothing is done with the records beyond personal comparison year by year. However, "phenology when properly organized goes much further than this, and when the data from hundreds of observers are sifted, tabulated and averaged some striking facts relative to climate, wild life and cycles are often revealed." Phenological lists are few for arctic and subarctic regions, obviously owing to the lack of observers in these areas at the proper time. The purpose of this note is to record the "first appearances" of some birds in the vicinity of Gambell in 1966 (see table 1 ). It is realized that one year of observations does not provide significant information as it stands alone; however, many avian spring arrival dates have been previously recorded in this area by Fay and Cade (1959) and provide a basis for comparison. Table 1 shows the spring arrival dates for 25 species of birds plus 12 species already present in the area at the time of my arrival in Gambell on May 13. Where possible, spring arrival dates for the same species have been taken from Fay and Cade (op. cit.); those species with spring arrival dates for more than one year have been averaged to give the date which appears in table 1.

\section{LITERATURE CITED}

Fay, F. H., and T. J. Cade. 1959. An ecological analysis of the avifauna of St. Lawrence Island, Alaska. Univ. Calif. Publ. Zool., $63: 73-150$.

Glendenning, R. 1943. Phenology the most natural of sciences. Can. Field-Nat. $57: 75-78$.

Leopold, A., and S. E. Jones. 1947. A phenological record for Sauk and Dane Counties, Wisconsin, 1935-1945. Ficol. Mono., 17:81122.

\section{POSSIBLE SIGHTING OF A GREEN HERON}

by C. A. Matthews, 827 Fourth Ave., Saskatoon

On June 22, 1966 Roy Murray and I were driving along a small creek draining into Payne Lake east and south of Radville, Saskatchewan. Sitting on pasture land close to the creek were three Black-crowned Night Herons, with their characteristic long crests. A few feet from the nearest night heron was a bird about twothirds of the size of the night herons, a much darker bird with no crest but with much brighter coloured legs: When we stepped out of the car, the smaller bird flew off to the northeast while the night herons remained. We believed it to be a Green Heron.

The A.O.U. Check-list of North American birds (1957) states that the Green Heron breeds in southeastern South Dakota and in spring and summer will wander north to southern Manitoba (Brandon) and to northeastern North Dakota. It is not listed in Birds of Alberta by Salt and Wilk (1966) and is not on the Saskatchewan field check-list, nor is it listed for either of these provinces in Earl Godfrey's Birds of Canada (1966).

It should be stressed that this report is just of a possible sighting, not a positive observation of a Green Heron, but it will serve to alert people in the area to the possibility of a wanderer appearing. 